\title{
Moving Beyond Judicial Conflict in the Name of the Pre-Eminence of Fundamental Human Rights
}

\author{
Valerio Onida
}

\begin{abstract}
Sentenza 238/2014 can be criticized insofar as it seems to ground Italy's refusal to comply with the Jurisdictional Immunities Judgment of the International Court of Justice on the basis of the right of access to a judge for the victims of the conduct of German armed forces during World War II. Indeed, the principle of state's immunity to the civil jurisdiction of other states regarding the conduct of their own armed forces does not in itself breach a victim's right of access to a judge, which theoretically in this case might also be granted by a German court. However, Sentenza 238/2014 has the merit of highlighting, in the specific case of the Italian Military Internees (IMIs), the violation of the victims' right to an effective judicial protection of their fundamental rights, given that German jurisdictions excluded every reparation that favoured IMIs. Such fundamental rights must prevail over the international rules relating to state immunity because, according to the supreme principles of the Italian constitutional order and to international law itself, fundamental human rights violations related to crimes against humanity must benefit from an effective protection. The impasse between Italy and Germany should be solved through a new joint initiative between the two governments (carried out ideally under a common understanding of the two Presidents of the Republic), which should examine the applicants' cases in order to grant them reparation. Though symbolic, such reparation will have an important moral dimension.
\end{abstract}

\section{Introduction}

The situation following the adoption of the 2012 International Court of Justice (ICJ) Judgment-which holds that the German state is not subject to the jurisdiction of Italian courts for proceedings brought by former Italian Military Internees (IMIs) or their families, and other victims of acts carried out by German armed forces in Italy

\footnotetext{
V. Onida $(\bowtie)$

University of Milan, Faculty of Law, Milan, Italy (emeritus)

e-mail: valerio.onida@oralex.eu 
after the armistice of September $1943^{1}$ —and the adoption of Judgment 238/2014 of the Italian Constitutional Court (ItCC), which ruled the Italian law purporting to implement the 2012 ICJ Judgment unconstitutional, ${ }^{2}$ is apparently unsolvable in terms of formal law. The conflict is not in fact between the Italian and the German governments but between an international court, by the rulings of which the states of the international community are bound, and a national constitutional court, the rulings of which are binding on the Italian government and legislature and are not subject to any form of appeal (Article 137(3) of the Italian Constitution).

\section{Quid Iuris or Quid Iustum?}

The ItCC did not deny that Italy is subject in general terms to a duty to abide by the judgments of the ICJ concerning the Italian state. However, it rejected the view that the provision of international law on which this particular ICJ Judgment was based (namely the exemption of the German state from Italian civil jurisdiction for acts carried out by German armed forces, even where these acts involved the commission of war crimes and crimes against humanity) could be applied in Italy and thus annulled the provision of Italian law, which had by contrast purported to assert this exemption in line with the 2012 ICJ Judgment. ${ }^{3}$

Thus, if we pose the question of quid iuris-namely, what is the rule of law that must apply in this case?-we cannot avoid establishing the existence of an irreconcilable conflict between international law and Italian law. In keeping with a 'dualist' conception of relations between the two legal systems, we would have to content ourselves with concluding that, in this case, the two systems do not express the same rule or stipulate any rule for harmonization but rather the two rules conflict irreconcilably with each other, and therefore offer different solutions to the specific disputes.

However, if we ask the question of quid iustum - namely, what would be a fair solution to this specific case?-we can no longer content ourselves with only noting the conflict between the two legal systems but must answer a different question: within the dispute between the Italian victims of crimes against humanity committed by German armed forces and the German state (legislature and judiciary), which has refused to recognize a right of redress to victims, should not the fundamental rights of the individual prevail over the rule providing for exemption from Italian jurisdiction, which has been inferred from international law?

This case in fact involves a conflict between two values: on the one hand, the need to grant immunity from jurisdiction to the actions of the armed forces of a state

\footnotetext{
${ }^{1}$ ICJ, Jurisdictional Immunities of the State (Germany v Italy: Greece intervening), Judgment, ICJ Reports 2012, 99, paras 79, 80, 91, 97, 101-103.

${ }^{2}$ Corte Costituzionale, Judgment of 22 October 2014, No 238/2014, para 4.1.

${ }^{3}$ ItCC, Judgment 238/2014 (n 2), para 4.1.
} 
operating within the territory of another state (and in their dealings with the nationals of that other state), based on the doctrine of state sovereignty and the characteristics of the state of war; on the other hand, the requirement to respect the fundamental rights of the persons involved. Nevertheless, defending the fundamental rights of individuals, including in particular those rights that we normally consider irreducible and inviolable, must inevitably prevail not only in moral terms but also from a legal standpoint (in terms of the universal law that humanity generally recognizes as a matter of principle, though frequently violated). This may be inferred for example from proclamations such as those set forth in Article 1 of the German Constitution, which proclaims the inviolability of human dignity, or in Article 15(2) of the European Convention on Human Rights, which prohibits any derogation, even during time of emergency, from the core fundamental rights to life and to the prohibition of torture and slavery.

\section{The Right to an Effective Judicial Protection}

The principle of prevalence of the fundamental human rights is worth both for international law and for domestic law and prevails over other norms, including constitutional provisions (for Italian law, this is expressed through the assertion that the supreme principles of the constitutional order prevail over any other provision, including those of constitutional law). Moreover, it is precisely in this vein that in Sentenza 238/2014 the ItCC refused to incorporate into Italian law rules that were at odds with the principle of prevalence of human fundamental rights.

It could be objected that, in this case, the ItCC did not expressly invoke rights such as the right to life or the prohibition of torture or slavery but the right to judicial protection, which it held to prevail over the principle of state immunity from the civil jurisdiction of other states in cases involving war crimes or crimes against humanity. However, the right to effective judicial protection is an 'instrumental' right, the guarantee of which is a prerequisite for the effective protection of other rights: to deny it when protection is sought for rights violated by crimes against humanity would be tantamount to denying these other rights.

It may be observed that the ItCC perhaps did not sufficiently stress that the case involved not the right to judicial protection in general, but the fundamental right to effective judicial protection for fundamental rights that were violated by crimes against humanity committed by German troops against IMIs and other similarly situated victims of Nazi crimes. ${ }^{4}$ In fact, considered in itself, the right to judicial protection could have also been guaranteed to the interested parties via access to a German court. The point is that the German courts, acting in accordance with

\footnotetext{
${ }^{4}$ ItCC, Judgment 238/2014 (n 2), paras 3.4, 3.5. For a different perspective, see Christian Tomuschat, chapter 'The Illusion of Perfect Justice', Alessandro Bufalini, chapter 'Waiting for Negotiations', and Sabino Cassese, chapter 'Recollections of a Judge', in this volume.
} 
German law, refused the claimants the right to any redress, by failing to allow them to benefit from compensation awarded to other classes of victims. ${ }^{5}$

Theoretically, it would have been possible for the Italian victims who had also brought an action before a German court to obtain judicial protection before those courts, perhaps according to a different interpretation of German law or even by a ruling by the German Federal Constitutional Court, ruling in the name of the very same supreme principles which the Italian court invoked in order to preclude the applicability of the 2012 ICJ Judgment. However, in view of the stance taken by the German legislature and courts, the effective judicial protection sought could only specifically be achieved through the disapplication-in this specific case-of the 2012 ICJ Judgment along with the Italian law requiring compliance with it.

This is not to negate the validity and effect of international law, as it were, from the perspective of 'nationalist' closure. In fact, both international law and state law (or at least the domestic law of states that have adhered to UN conventions on the protection of human rights and the prevention and punishment of war crimes ${ }^{6}$ ) cannot avoid recognizing the pre-eminence and hence the predominance of the principle of fundamental human rights protection: even where it conflicts with other legal principles, such as the principle of state immunity before the courts of another state regarding acts carried out by the armed forces of the first one in the territory of the second. In this area, absent any ad hoc international tribunal, a universal principle that guarantees effective judicial protection to victims must also apply before civil courts.

\section{Conclusion}

Since it is difficult to give a specific (quantitative) form to the right to compensation for damages against the German state in accordance with general national principles of civil law, it is clear that it would be appropriate, and in fact necessary, for a new agreement to be reached between the German and the Italian government, something that the ICJ itself stated would be desirable.

On the other hand, to leave the Italian courts to issue rulings against the German state whilst subsequently refusing to enforce these judgments, thereby separating the

\footnotetext{
${ }^{5}$ See Bundesverfassungsgericht, Order of 28 June 2004, 2 BvR 1379/01, BVerfGK 3, 277; Verwaltungsgericht Berlin, Judgment of 9 September 2004, 9 A 336.02. In this context, see also the Distomo cases where German courts refused to grant redress to Greek victims of World War II massacres: Bundesverfassungsgericht, Order of 15 February 2006, 2 BvR 1476/03, BVerfGK 7, 303. See also Andreas von Arnauld, chapter 'Deadlocked in Dualism', in this volume.

${ }^{6}$ See for instance International Covenant on Civil and Political Rights, 16 December 1966; Convention on the Non-Applicability of Statutory Limitations to War Crimes and Crimes Against Humanity, 26 November 1968.
} 
judicial recognition of the right from the question of enforcement, ${ }^{7}$ would not be a good solution. This would in fact amount to a hypocritical and formalist solution and would not resolve the conflict, which instead calls for a substantive and mutually agreed solution.

Within the framework of the new agreement, it would be possible for the two states to recognize that under the historical circumstances that led to the crimes in question they both bear some form of responsibility. ${ }^{8}$ It would also be possible to establish criteria for defining the status of 'victims', enabling the recognition of moral responsibilities and the quantification of the (largely symbolic) compensations due. I believe that those who have taken action before the Italian courts, as victims or as family members of victims, have done so not so much with the aim of securing financial redress-given that the damages suffered cannot be compensated-but also, and perhaps principally, with the purpose to get a moral recognition of their status as victims.

It would be highly desirable for a new agreement to be called for and promoted by the Heads of State of Italy and Germany acting in concert with each other in order to express at the highest level considerations rooted in the shared recognition (also within the common European context), of the same principles of respect for and protection of fundamental human rights that would serve as a basis and a justification for such an agreement. ${ }^{9}$

Open Access This chapter is licensed under the terms of the Creative Commons Attribution 4.0 International License (http://creativecommons.org/licenses/by/4.0/), which permits use, sharing, adaptation, distribution and reproduction in any medium or format, as long as you give appropriate credit to the original author(s) and the source, provide a link to the Creative Commons license and indicate if changes were made.

The images or other third party material in this chapter are included in the chapter's Creative Commons license, unless indicated otherwise in a credit line to the material. If material is not included in the chapter's Creative Commons license and your intended use is not permitted by statutory regulation or exceeds the permitted use, you will need to obtain permission directly from the copyright holder.

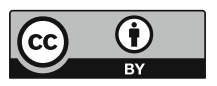

\footnotetext{
${ }^{7}$ See also Paolo Palchetti, chapter 'Right of Access to (Italian) Courts über alles?', and Giovanni Boggero/Karin Oellers-Frahm, chapter 'Between Cynicism and Idealism', in this volume.

${ }^{8}$ In fact, at the time the events occurred, there were two opposing governments in Italy: the legitimate government, which had signed the armistice along with the partisans fighting the German troops, and the Fascist Republic of Salò, which was allied with the Nazis. See also Andreas von Arnauld, chapter 'Deadlocked in Dualism', in this volume.

${ }^{9}$ See also Filippo Fontanelli, chapter 'Sketches for a Reparation Scheme', and Francesco Francioni, chapter 'Overcoming the Judicial Conundrum', in this volume.
} 